\title{
Ayurveda Management of Kampavata with special reference to Parkinson's Disease- A Single Case Study
}

\author{
Nandkishor Pralhadrao Umale ${ }^{1}$, Priya Pillai $^{2}$ \\ ${ }^{1}$ Assocaite Professor, Department of Panchakarma, Parul Institute of Ayurveda and Research \\ Vadodara, Gujarat, India \\ ${ }^{2}$ Assistant Professor, Dept. of Panchakarma, Suryansh Arogyashala, Jayoti Vidyapeeth \\ Women's University, Jaipur, India
}

\begin{abstract}
:
Parkinson's disease is a progressive degenerative neurological disorder which mainly affects the motor system of body and it is characterized by resting tremors, slowness of movements, rigidity, gait disturbances/postural instability. It is correlated with Kampa Vata [Disease associated with tremors in body] in Ayurveda, [Indian ancient science for healthy life] as it is characterized by Sarvanga Kampa / Shiro Kampa [tremors all over body or tremors in head]. It is a Vata Vyadhi [principal element of body which caused diseases] which occurs due to pathological increase of Chala Guna [Moving property] of Vata. [Principal element of body] Treatment consists of both internal and external administration of different forms aimed to reverse pathology of Vata imbalance. Here, a case of 57 years male patient presented with tremors in both hands and neck, unable to walk without support since 12 years. Patient was treated with Panchakarma therapies; like Sarvanga Abhyanga, [External oil massage] Nadi Sweda, [sudation therapy] Shiro Abhyanga [Head massage], Shiro Pichu [Oil soaked cotton pad putting on head] and Shiro Basti [Retension of oil on head] and Shamana Aushadhis like Tab Vatachintamani Rasa, Kapikachu Beeja Choorna [Mucuna pruriens], Ashwagandha Choorna, [Withamnia somnifera] Cap Ksheerabala 101, Avipatikara Choorna for 1 month. The patient got remarkable relief in symptoms with above Panchakarma and Ayurveda medicines.
\end{abstract}

Key Words: Kampavata, Parkinson's disease, Tremors, Vata.

Received: 15.04.2021 Revised: 18.05.2021 Accepted: 07.06.2021 Published: 28.06.2021

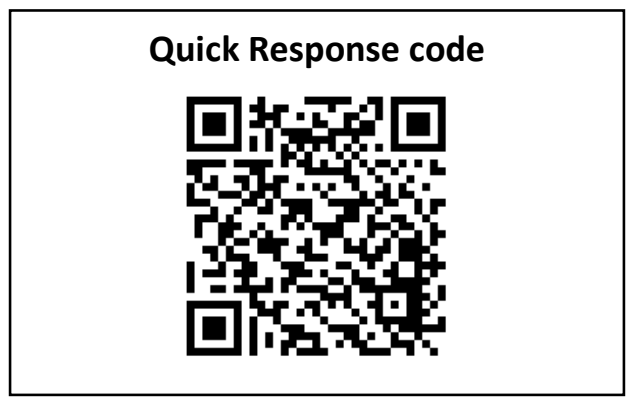

*CORRESPONDING AUTHOR:

Dr. Nandkishor Pralhadrao Umale

Associate Professor, Department of Panchakarma,

Parul Institute of Ayurveda and Research, Vadodara

Gujarat -391760

E-mail : nandkishor293@gmail.com 


\section{Introduction:}

Kampavata is one among vataja nanatmaja vyadhi explained by Acharya Charka in sutrasthana ${ }^{[1]}$ Kampa is the prominent feature in kampavata which is mainly caused by the vitiation of vata. In early stages it can be manage with combine approach of shodhana like virechana [Medicated purgation therapy], vasti [medicated enema], nasya [Nasal drops], Murdhni taila [4 specific treatment of head told for diseases related to head], ${ }^{[2]}$ along with shamana drugs like Kapikacchu, Ashwagandha, Bala [ Sida cordifolia] and Brumhana drugs. Murdhini Tailas which are known as Shirastharpana are the process of applying medicated oil to the Murdha [Head] for a stipulated time period. Head is considered as Uttamanga in Shareera by Acharyas so, it is essential to protect the head from any sorts of disease attacks. Taila is the best source for curing/ balancing the abnormal Vata Dosha. So, by means of Murdhini Taila we can achieve a drastic control over Vataja disorders mainly related to Murdha Pradesha. Murdhini Tailas are of four types which show a progressive mode of action in ascending order and is as follows:-

1. Shiro Abhyanga - Massaging of head by using medicated oil.

2. Shiro Dhara - Pouring of medicated oil /buttermilk, Kashaya etc. over forehead for a stipulated time period.

3. Shiro Pichu - It is the procedure of applying medicated oil to the vertex using a cotton pad impregnated with suitable medicated oil.

4. Shiro Basti - Here, the medicated oil is poured over the head and is allowed to remain there for certain time period and it is having the ultimate effect while comparing to all the above 3 procedures. [3]

All the above procedures hold an undefined role in the treatment of Kampavata and among that Shiro Basti was having the miraculous power to give relief for the patient.
Parkinson's disease is a progressive neurodegenerative disorder which mostly affecting older adult making them crippled as disease progresses. Parkinsonism is typically characterized by fine pin rolling tremors which is progressive in nature, rigidity in extremities, difficulty in walking, unable to balance the body and slow walk/ short shuffling gait. The incidences and prevalence of Parkinson's disease increases with advancing age found in $1 \%$ of people over the age of 64 year. ${ }^{[4]}$ This disease can be correlated as Kampa Vata in Ayurveda. Previous case study showed significant improvement in patients who are treated with Moolakadi Taila Nasya and Matra Vasti for the period of 16 days. [5] Another study also showed Sarvanga abhynga with Ksheerbala taila, swedana, Yapana Vasti, Nasys helps to improve patients diseased condition of parkinsonism. ${ }^{[6]}$ So depending upon above findings treatment has been planned in this patient.

\section{Case presentation:}

A male patient of age 57 years brought to Panchakarma OPD of Suryansh Arogyashala, Jayoti Vidyapeeth Women's University, Jaipur by his relatives complaining of Sarvanga Kampa increasing since 12 years, more in head, neck and in upper extremities, difficulty in walking, able to walk with support only, stiffness in whole body, unable to talk properly, unable to have food and drink by hands. History of present illness shows that patient was well before 12 years. Suddenly while travelling, he met with a road traffic accident in which there is blunt trauma to back and head, patient recovered from this with the help of routine treatment given by physician. After six months from this incidence, he developed slight tremors of head and hands which were progressive in nature. Later, after few months, patient was unable to perform his work also. Family history is positive for Parkinsonism from both maternal and paternal side. Patient was non-alcoholic, chronic tobacco chewer but as symptoms appeared he 
stopped tobacco chewing. Patient went to take treatment but due to financial crises, he stopped the medicine.

In general examination-BP - 100/76 mm of Hg, PR - 68/min regular, RR - 17/min, Pallor Presen, Icterus - Absent, Bowel habit - 1 time per day with slight constipation, Micturition 3 - 4 times per day, clubbing / cyanosis Absent.

In systemic examination findings were noted as

- Respiratory system :- Chest-bilaterally symmetrical, Air entry- both sides normal, no added sounds heard

- Cardiovascular system :- S1, S2 heard, no Murmur

- Gastrointestinal system :- Per abdomen soft, no organomegaly, no palpation

- Locomotor system :- Thin built patient, slight kyphosis, unable to walk and balance without support

- Nervous System:- Patient was conscious, oriented about place and time, higher mental functions intact, Pupil - NSERL, tremors present in neck, both hands, grip is present but with tremors.
Reflexes: Planter reflex - Flexor

Ankle jerk - Right ++,

Left ++

Knee jerk- $\quad$ Right ++ ,

Left ++++ ,

Biceps jerk - $\quad$ Right ++ ,

Left ++

Triceps jerk - $\quad$ Right ++ ,

Left ++

Muscle power- Right upper 5/5

Left upper $5 / 5$

Right lower limb 5/5,

Left lower limb 5/5

Muscle Tone, $\operatorname{Cog}$ wheel type Rigidity was seen in $\mathrm{B} / \mathrm{L}$ lower limbs. He had a flexed posture with mask face.

Diagnosis of patient done based upon clinical features and as patient is well diagnosed from 12 years. Patient was assessed using Hoehn and Yahr Scale and Parkinson's disease composite scale ${ }^{[7-8]}$ On the basis of Hoehn and Yahr Scale scale patient was at stage 4 in this assessment (Table-1). On the basis of Parkinson's disease composite scale the assessment was done before and after treatment (Table-2).

Table-1: Hoehn and Yahr Scale:

\begin{tabular}{|l|l|}
\hline Stage & Hoehn and Yahr Scale \\
\hline 1 & Unilateral involvement only usually with minimal or no functional disability \\
\hline 1.5 & Unilateral and axial involvement \\
\hline 2 & Bilateral or midline involvement without impairment of balance \\
\hline 2.5 & Mild bilateral disease with recovery on pull test \\
\hline 3 & $\begin{array}{l}\text { Bilateral disease: mild to moderate disability with impaired postural reflexes; physically } \\
\text { independent }\end{array}$ \\
\hline 4 & Severely disabling disease; still able to walk or stand unassisted \\
\hline 5 & Confinement to bed or wheelchair unless aided \\
\hline
\end{tabular}




\section{INTERNATIONAL JOURNAL OF AYUSH CASE REPORTS (IJA-CARE)}

Table-2: Parkinson's disease Composite Scale:

\begin{tabular}{|l|l|l|l|}
\hline Symptoms & $\begin{array}{l}\text { Total } \\
\text { Score }\end{array}$ & $\begin{array}{l}\text { Score found in } \\
\text { patient during first } \\
\text { evaluation }\end{array}$ & $\begin{array}{l}\text { Score after one } \\
\text { month }\end{array}$ \\
\hline Bradykinesia & 4 & 3 & 2 \\
\hline Tremors & 4 & 4 & 2 \\
\hline Gait & 4 & 3 & 1 \\
\hline Balance /Postural Disability & 4 & 3 & 1 \\
\hline Freezing & 4 & 0 & 0 \\
\hline Nocturnal Akinesia & 4 & 2 & 1 \\
\hline Fatigue & 4 & 2 & 1 \\
\hline Urinary & 4 & 2 & 1 \\
\hline Cognitive Impairment & 4 & 1 & 1 \\
\hline Depression / Anxiety & 4 & 1 & 0 \\
\hline Symptomatic or Orthostatic Hypotension & 4 & 3 & 2 \\
\hline Hallucination or thought disorder & 4 & 1 & 0 \\
\hline Dyskinesia & 4 & 4 & 2 \\
\hline Dystonia & 4 & 2 & 1 \\
\hline ON/OFF & 4 & 4 & 2 \\
\hline Dopamine Dysregulation syndrome & 4 & 0 & 0 \\
\hline Disability & 4 & 4 & 2 \\
\hline & 68 & 39 & 19 \\
\hline
\end{tabular}

Table-3: Therapeutic intervention (Panchakarma and shaman treatment):

\begin{tabular}{|c|c|c|}
\hline Medicines & Dose, time \& anupan & Total duration \\
\hline $\begin{array}{l}\text { Kapikachu Beeja Choorna } \\
{ }^{9} \text { (Mucuna } \quad \text { Pruriens) } \\
\text { Ashwagandha Choorna }{ }^{[10]}\end{array}$ & $\begin{array}{l}5 \mathrm{gm} \text { each in morning time with } \\
\text { milk }\end{array}$ & 1 month \\
\hline Cap Ksheerabala-101 & $\begin{array}{l}1 \text { cap Three times a day after } \\
\text { food with plane water }\end{array}$ & 1 month \\
\hline Avipatikara Choorna $^{[12]}$ & $\begin{array}{l}5 \mathrm{gm} \text { at night time after food } \\
\text { with warm water }\end{array}$ & 1 month \\
\hline Shiro Abhyanga & Brahmi Taila $^{[13]}$ & 10 days \\
\hline $\begin{array}{l}\text { Sarvanga Abhyanga followed } \\
\text { by Bashpa Sweda }\end{array}$ & Maha Narayana Taila ${ }^{[14]}$ & 1month \\
\hline Shiro Pichu & Brahmi Taila & From $11^{\text {th }}$ day to $20^{\text {th }}$ day \\
\hline Tab Vatachintamani Rasa ${ }^{[15]}$ & $\begin{array}{l}1 \text { tab two times a day with } \\
\text { honey at } 8 \text { am and } 6 \text { pm daily }\end{array}$ & 20 days \\
\hline Shiro Basti & $\begin{array}{l}\text { Moorchita Tila } \\
\text { Brahmi Taila }\end{array}$ & From $21^{\text {st }}$ day to $30^{\text {th }}$ day \\
\hline
\end{tabular}


The patient was followed up along with following medications:-

\section{Kapikachu Beeja Choorna + Ashwagandha Choorna 5gm each in morning time with milk for 1 month}

2. Tab Vatachintamani Rasa 1 tab two times a day with honey at $8 \mathrm{am}$ and $6 \mathrm{pm}$ daily for 1month.

3. Shiro Abhyanga [application of oil over head] with Brahmi Taila

\section{Outcome and follow-up:}

Patient shows mild to moderate degree of improvement in the symptoms. Hoehn and Yahr Scale changes to 3 after 15 days and changed to 2.5 after 1 month. Parkinson's disease Composite Scale also showed some changes which was reduced from 39 to 19 . During follow up, patient's symptoms was slightly increased as he discontinued the medications.

\section{Discussion:}

As Kampa Vata is a Vata Vyadhi, which is a progressive neurological disorder due to impairment in Chala Guna of Vata, so that Vatahara treatment should be adopted for this, both external as well as internal. When Vata is vitiated to its peak level, it tends to deplete all the tissues in the body; the Pitta and Kapha Doshas, the immunity and life span of an individual. Thus control of Vata is the only key in treatment of Parkinson's disease. Hence, removal of strotodushti, Vata Shamana, Vatanulomana and Rasayana therapy by the administration of effective medication and treatment will lead to effective cure of Parkinson's disease and also have to avoid Vata Prakopakara Ahara and Vihara. ${ }^{[17]}$ So, here Shiro Abhyanga, Sarvanga Abhyanga, Bashpa Sweda, Shiro Pichu and Shiro Basti were adopted to calm the Prakupitha Vata as external measures. Here, for Shiro Abhyanga, Shiro Pichu and Shiro Basti were done by using Brahmi Taila due to its Medhya Rasayana and stress relieving action which helps to calm the nervous system as Kampa Vata is a neuro degenerative disease, it is treated by Rasayana approach in Ayurveda.; so that, his damaged nerves gets proper stimulation by means of proper increase blood circulation to brain which inturns help in reverse the pathological process to an extent. Sarvanga Abhyanga with Maha Narayana Taila will helps in the strengthening of muscles, bones and joints, provides analgesic effect, nourishment of Sushka Dhathus and also do Vatahara and Vatanulomana action by doing Abhyanga in Anuloma Gati which will also hampers the Viguna Gati of Vata Dosha in the pathology. Bashpa Sweda using Vatahara Kashaya will also help in Vatahara action and also helps in reducing the stiffness of the body. ${ }^{[18]}$

Internally, Kapikachu Beeja Churna was given which contain natural source of I-dopa. It replenishes depleted stores of striatal dopamine. ${ }^{[19]}$ Ashwagandha Churna is also given which is a Rasayana drug, as Rasayana drugs are essentially nutritional agents and Medhya Rasayana are specific nerve tonics with nootropic effect. [20] This is because; Ayurveda considers this type of movement disorders under Vata Dosha Vikaras and to overcome the neuro nutrients by Rasayana remedies. Avipathikara Churna was given for the attaining the Anuloma Gati $^{21}$ of Mala and also for correction of agni as it is told that "Sarve Roge Api Mandhagnau" in Ayurveda and also for the treatment of any disease, Agni should be proper first. ${ }^{[21]}$ Vata Chintamani Rasa was also given as it is a yoga which contains Roupya Bhasma, Abhraka Bhasma, Loha Bhasma, Rasa Sindura, Pravala Bhasma and Moti Bhasma which was having rejuvenating, catalytic, antioxidant, immune modulating, and strength promoting action along with Vatahara Rasayana property. So, it is used in treatment of Kampavata. ${ }^{[22]}$ 


\section{Conclusion:}

Kampavata can be compared with Parkinson's diseases depending on symptomalogy of patient. Panchakarma can create miracles in one's own life along because of ability of evacuation, superiority of efficacy and enormity of the procedures to target dosha eradication. Murdhini Taila along with rasayana drugs shows its ultimate action in this case. Abhyanga, Swedana, Nasya, Niruha, Anuvasana, Virechana and Shiro Basti, are the useful measures that can increase the life expectancy of the patient. So, it can be concluded that both Samshodana and Samshamana Chikitsa plays an excellent role in improving the day-to-day activities of a Kampa Vata patient if adopted properly and regularly.

\section{Limitation of the study:}

Parkinson's disease is progressive neurodegenerative disorder so difficult to comment about absolute treatment in such short period of time. Further more studies with large sample size along with control group are needed for establishment of action of Panchakarma in this disease condition.

\section{Consent of patient:}

A written consent was obtained from the patient and patient's relative before starting of the Panchakarma treatment and before writing case report of the patient.

\section{Acknowledgement:}

I want to acknowledge staff of Suryansh Arogyashala, Jayoti Vidyapeeth Women's University, for their constant support during conduction of study.

\section{References:}

1. Shastri R. Charak Samhita, Vidyotini hindi commentary part I Sutrasthana chapter 20/11, reprinted edition, Pub: Bharathi academy, Varanasi, 2001; p-399.

2. Saxena N. Vangasena vol. I 28/155 edition, Pub: Chaukhamba Krishnadas Academy, Varanasi, 2004; p409.

3. Gupt KA. Ashtanga Hridaya, Sutra Sthana 22/23-26, Chaukhamba Sanskruta Sansthana, Varanasi Ed 2000 p- 134.

4. Goldman SM, Tanner C. Etiology of Parkinson's disease. In: Jankovic J, Tolosa E, editors. Parkinson's's disease and movement disorders, $3^{\text {rd }}$ ed. Baltimore, MD: Lippincott-Williams and Wilkins; 1998. P-133-48

5. Gaur G, Pal S, Kulratan, Kampavata with special reference to parkinson's disease- a case study, International Journal of Development Research, 2018;8 (9): 23026-23028

6. Varma J, Kasvan N, Mangal G. Management of kampavata with special refrence to Parkinson's disease through Panchakarma - a case report, World Journal of Pharmaceuticals and life sciences. 2018; 4(10):115-119

7. https://www.epda.eu.com/aboutparkinsons /symptoms/rating-scales/ [Last accessed on 10.03.2021]

8. https://www.epda.eu.com/aboutparkinsons /symptoms/rating-scales/ [Last accessed on 10.03.2021]

9. Katzenschlager R, Evans A, Manson A. Mucuna pruriens in Parkinson's disease: a double blind clinical and pharmacological study. Journal of Neurology, Neurosurgery and Psychiatry 2004; 75: 1672-1677

10. Singh N, Bhalla M, Jager P, Gilca M. An Overview on Ashwagandha: A Rasayana (Rejuvenator) of Ayurveda, Afr J Tradit 
Complement Altern Med. 2011;8(5 Suppl): 208-213.

11. Gupt KA. Ashtanga Hridaya, Chikitsa sthana 22/45-46, Chaukhamba Sanskruta Sansthana, Varanasi Ed 2000 p 426

12. Mishra SN. Bhaishjya ratnavali of Govinda das sen amlapitta adhikara 56/2428, Chaukhamba Surbharati Prakashana Varanasi 2013 p 903

13. Madhavika P Chaudhari, KSR Prasad, Bramhi Taila Shiro Abhyanga in chittaudvega (Anxiety Neurosis), Journal of Indian System of Medicine. 2014; 2(3):127-131

14. Shastri A. Bhaishajya ratnawali by Goving Das, Vatavyadhi chikitsita, 26/343-354, Varanasi: Chaukhamba prakashan; Reprint 2011. P-539- 540.

15. Mishra SN. Bhaishjya ratnavali of Govinda das sen Vatavyadhi Chikitsa 26/141-144, Chaukhamba Surbharati Prakashana Varanasi 2013 p-530-531

16. Murthy KRS. Sharangdhar Samhita Madhyama Khanda 9/14, Chaukhamba Orientala Varanasi 2009 p-324

17. Gupt KA. Ashtanga Hridaya, Sutra Sthana 13/1-3, Chaukhamba Sanskruta Sansthana, Varanasi Ed 2000 p- 96.

18. Tripathi B. Charaka Samhita Sutra sthana 22/11, chaukhamba surabhi Prakashana Varanasi 2014 p-413.

19. Katzenschlager R, Evans A, Manson A. Mucuna pruriens in Parkinson's disease: a double blindclinical and pharmacological study. Journal of Neurology, Neurosurgery and Psychiatry 2004; 75: 1672-1677.

20. Singh N, Bhalla M, Jager P, Gilca M. An overview on ashwagandha: a Rasayana (rejuvenator) of Ayurveda. African Journal of Traditional Complementary Alternative Medicine. 2011; 8(5 Suppl): 208-213.

21. Shastri AD, Shastri RD. Ayurvedshashtracharya, Bhaishaajya Ratnavali - with the vidyotini hindi commentary, Chaukhambha Sanskrit Sanstha, Varanasi. $8^{\text {th }}$ edition 1987 , p644.

22. Goshan V, Mundugaru R, Prakash N, Bhat $\mathrm{S}$, Basavaiah R. Evaluation of neuroprotective activity of Brihatvata Chinthamani Rasa. The Journal of Phytopharmacology 2015; 4(4):207-211.

Conflict of interest: Author declares that there is no conflict of interest.

Guarantor: Corresponding author is guarantor of this article and its contents.

\section{Source of support: None}

\section{How to cite this article:}

Umale NP, Pillai P. Ayurveda Management of Kampavata with special reference to Parkinson's Disease- A Single Case Study. Int. J. AYUSH CaRe. 2021; 5(2):64-70 